\title{
Impulsive Openness: \\ Boredom and Bio-politics
}

\author{
Mark Jackson
}

\section{Introduction}

In a book remarkable for the brevity in which its prose develops considerable complexity, Giorgio Agamben interrogates animal being. The Open: Man and Animal has at its core Agamben's reading of Martin Heidegger's 1929-30 lecture course, published as The Fundamental Concepts of Metaphys$i c s$. As Agamben notes, the contents of this lecture course do not necessarily hold what one might have expected from the title. About a third of the publication concerns a discussion of 'boredom' as a fundamental attunement of being-in-the-world; another third is concerned with a determination of the essence of animality in the disclosure that animal is poor in world'. The remaining third is concerned with the world forming of world as the disclosure of Dasein's being-in-the-world. Agamben approaches the Heidegger text for how Heidegger is able in a non-contradictory way to speak of 'the open' with respect to both animal and human being while yet designating a fundamental abyss between the essence of animal and the essence of human being.

And Agamben inflects his engagement with Heidegger concerning the fundamental condition for defining 'life' in terms of a notion of the biopolitical. In an earlier book, Homo Sacer: Sovereign Power and Bare Life, Agamben takes up Michel Foucault's engagements with governmentality and modernity in terms of the governance of 'bare life' of populations, or the biopolitics of living beings. In The Open Agamben further articulates the difficult notion of 'bare life' and brings an engagement with biopower into the orbit of Heideggerian thinking. In this paper I want to assay these aspects of Agamben's argument in The Open, firstly in relation to Heidegger's own account of animality; secondly, in terms of the proximity of Dasein to animality in the fundamental attunement of Dasein in 'boredom'; and, thirdly, in terms of how Agamben reads Heidegger's concerns as fundamentally political. Perhaps, though, I should start with Heidegger's 'animal'. 


\section{A Break with Humanism}

In his 1923 lecture course, published as Ontology-The Hermeneutics of Facticity, Heidegger develops his notion of Dasein in fundamental distinction to the two predominant concepts of 'man', as 'the theological concept of man' and as 'animal rationale'. 'Man' has been that being that falls between a creation in the image of God and a 'living being [animal] which has discourse', which is to say between the divine and the inhuman. Heidegger's 'Dasein' is nothing human in either sense:

In choosing a term to designate this region of being and appropriately demarcate it, we have avoided the expression 'human Dasein,' 'human being,' and will continue to do so. In all of its traditional categorical forms, the concept of man fundamentally obstructs what we are supposed to bring into view as facticity. The question 'What is man?' blocks its own view of what it is really after with an object foreign to it. (Heidegger, 1999: 21)

I am mentioning this notion of the 'being-there' of Dasein in its 'being there for a while' in order to emphasise Heidegger's break both with humanism as an ego-centrism of the human and with any evolutionism implicit in a notion of 'rational animal'. In The Fundamental Concepts of Metaphysics, Heidegger aims at an understanding of the fundamental attunement of Dasein to its being in the world, to its being with beings, its world-forming. Dasein's being is its openness to Being, to the being of beings as a whole as those beings disclosed to it. Heidegger wants to come to some understanding of 'world' in the sense that 'man is world-forming'. He undertakes this by initially inquiring into animal being and its relation to world, which is to say in relation to animal being's relation to beings as a whole. He commences with a comparison of stone-being, animal-being and world-forming. Hence, the stone is 'worldless' in the sense that the stone has no access to beings. While the stone is a being, it has no access to beings and equally is not deprived of being. It is worldless: "The worldlessness of a being can now be defined as its having no access to those beings (as beings) amongst which this particular being with this specific manner of being is" (Heidegger, 1995: 197).

Hence, 'world' infers the accessibility of beings to beings. With respect to an animal, things are more complicated than for the stone. An animal, Heidegger suggests, is 'poor in world'. It both has and does not have world, which means it both does and does not as a being have access to beings. What does he mean? When Heidegger discusses world-formation and Dasein's relation to beings, he means that beings are disclosed in their present at handness for Dasein; that is, beings are disclosed in their being, in that they are as such. Animal being never has access to the present at handness of beings, to the beingness of beings. Beings are never disclosed to animal being in its dealing with its 'world' of things. Heidegger goes into some detail in describing the relation of animal being to its 'world' and in so doing arrives at what he terms the essence of animality as 'captivation':

Of course, this driven behaviour does not relate itself, and as captivated activity cannot relate itself, to what is present at hand as such. 
What is present at hand as such means what is present at hand in its being present at hand, as a being. ... The animal as such does not stand within a manifestation of beings. Neither its so-called environment nor the animal itself are manifest as beings. (248)

\section{Accessibility to Being}

Before addressing in any detail Heidegger's account of animal being's relation to beings, I want to emphasise what is at stake in Heidegger's questioning. When Heidegger initially enquires about stone, animal and man with respect to world, he arrived at the worldlessness of stone, the worldforming of man and the ambiguity of the animal which is in one sense closer to the stone as worldless and in another closer to man with world. But the decisive question is from what viewpoint can such a comparison be disclosed? Who questions? And what does the questioning question? Heidegger suggests: "The substantive problem with which we are concerned is precisely that of accessibility itself, the question concerning the potential access that man and animal characteristically have to other beings" (Heidegger, 1995: 201). But who questions? Human-being questions. Hence, "Can we transpose ourselves into an animal at all?" (201) Transposition does not mean transferring ourselves into the interior of another being, becoming that other being; nor does it mean going along with that other being as if we were that other being; nor does it mean having empathy for that other being as a feeling our way into that being. Rather, it firstly means understanding the being that we are as a being that has access to other beings and secondly, going along with the animal "in a way in which it sees and hears, the way in which it seizes its prey or evades its predators" (204).

That is to say, we understand that the animal in its dealings with its 'world' has access to beings, and in our going along with the animal we recognize that the 'sphere' of its 'world' offers the possibility of transposition. With the stone, matters are different. While the stone is a being, its being offers no possibility in our going along with it for our transposition to its sphere of being: "It is impossible because the stone as such does not admit of this possibility at all, offers no sphere intrinsically belonging to its being such that we could transpose ourselves into the stone" (204). There is a third question: can we transpose ourselves into another human being? Heidegger suggests this question seems to be the same question posed regarding animal being. We can go along with human beings in the possibility of transposing ourselves into the access they are with respect to the sphere of their world. But there is a fundamental difference. With human beings, it is no longer an intrinsic possibility that we may transpose our being into the being of other human beings. Rather, human being as Dasein is this transposition of existence into other human beings: "For it is part of the essential constitution of human Dasein that it intrinsically means being with others, that the factically existing human being always already and necessarily moves factically in a particular way of being with ..., i.e., a particular way of going along with" (206). In his analysis of accessibility of being to beings through the question of the giving of access itself, Heidegger arrives at a fundamental distinction between animal and Dasein. 


\section{Organ, Organism and Life}

In breaking with the doxa of thinking of an 'organ' as an instrument in a mechanistic thinking of organism, Heidegger suggests that the essence of 'organ' is 'capacity' or 'capability' understood as an "instinctual self-driving towards its wherefore" (Heidegger, 1995: 228-9). Are our organs, such as our eyes, equipment we see with, instruments of vision in a complex assemblage of instruments or pieces of equipment we call an organism? Equipment is in the service of something. It is produced to accomplish a task. Its essence is serviceability as reliability or readiness. Instruments are ready for a task. A pen is ready for writing, or (the same thing) not ready if it needs ink, or the ink won't flow. A pen has no capacity for writing, in the sense than an eye has a capacity for seeing. Yet, organs in themselves have no capacity except as relations to an organism as capacities, that is to say, the organ is in possession of a capacity, is given a capacity. The readiness of equipment is determined and prescriptive, and in this sense we would not say a piece of equipment is capable of such and such. Capability is selfregulative, as Heidegger suggests: "It drives itself towards it own capability for ..." (228). Such capability, constitutive of living organisms, is instinctually driven: "Capacity is to be found where there is drive" (228). Drive infers capacity, and capacity infers the possibility of training for regular behaviour:

These driving forces [Antriebe], which arise from the instinctual capacity in each case, do not as such merely occasion vital movements-like nutrition and propulsion-but rather as drives they always permeate and drive on the whole movement in advance. That is why they are never simply mechanical, even if they can be isolated in this way, i.e., by ignoring the instinctual structure of drives in which the specific potentiality for being and thus the manner of being belonging to these drives is embedded. In principle there is no mathematical expression for this instinctual structure of drives, and it is one which is incapable in principle of being mathematised. (229)

Heidegger thus defines the constitutive moment of the being of animal as 'being capable', which means being organized in the sense of being a self-producing, self-regulating, self-renewing and self-preserving being. By 'self' he is not anthropologising animality, in the sense of a self-conscious or reflective organizing. Rather, he means that such producing, regulating, renewing and preserving is the proper to the itself of animal being, what is closest to its being. That is to say, in its towardness, its potentiality for being, its movement in advance and anticipatory instinctual response, it does not leave itself behind. This, for Heidegger, would be constitutive of what we have named, and are primarily concerned with, as 'animal impulse'. And, as we will come to recognize in registering Agamben's concern with Heidegger's animality, animal impulse has the most complex complicity with Dasein's openness to being.

I mentioned earlier that Heidegger suggests the essence of animality is 'captivation'. What does he mean by that, and what would be the relation 
of 'captivation' to capability or capacity? Capability is the potentiality of the animal to be, which means its proper producing, regulating, renewing and preserving what is closest to itself in its being. In its being in the world it acts instinctually in its behaving in the world in its proper being, in being what is closest to it, its 'world' of other beings recognized as prey, nourishment, shelter, sexual partners and so on. Capability is capability for behaviour. And here Heidegger makes a further distinction between animal and 'man'. Animals behave in the sense that they act according to a driving performing, an instinctual drivenness; humans 'comport' as doing or acting: "The specific manner in which man is we shall call comportment and the specific manner in which the animal is we shall call behaviour. They are fundamentally different from one another" (237).

How, then, is animal behaviour to be characterized? Unlike the stone or the piece of equipment that have no access to beings, no drive or capability, the animal is open to beings in its 'world'. Its being is this openness to beings, its behaviour. Again, it is crucial to emphasise that we do not in some manner define animal being and then ask what does this being do in a world of things, just as we do not ask the question 'what is man' and then ask what 'man' does in a world of things. Rather, the disclosure of being is the disclosure of the being open of beings to their being in a 'world'. If Heidegger is emphatic on the distinction between animal-behaviour and human-comportment, he is equally emphatic on distinguishing between animal-environment and human world. World and environment come to designate different entities from the point of view of the disclosure of being. Heidegger will define the inner possibility of behaviour, as the openness of animal being to beings, which is to say to its environment, as 'captivation'. As the inner possibility of behaviour, 'captivation' refers not to a kind of enduring fixation an animal might have with its environment, a kind of seizure or mood that it cannot get over. Rather, it refers to the animal's absorption with itself, its remaining with itself, the specific manner whereby in its towardness, it does not leave itself behind. Captivation does not accompany behaviour; it is the possibility of behaviour.

How does the animal maintain the proper of itself in its towardness, its relatedness to beings, where this 'towardness' is also a moving-awayfrom in the traversing of an environment? As instinctual drivenness, the animal is 'given over' to beings: "It is not an apprehending of something as something, something present at hand. There is no apprehending, but only behaving here, a driven activity which we must grasp in this way because the apprehending of something as something is withheld from the animal' (247). This possibility of apprehension as such is 'not given at all'. In this sense, the animal is 'taken by things'. Hence, this access of animal being to beings as a relatedness to things, as an openness to beings, is at the same time a withholding of the being of beings, a closeness to being, to that something is as such. The open as a revealing of beings to animal being is at the same time a concealing of the beingness of beings. Strictly speaking, as a withholding of being, the open of animal being to things is neither openness to being nor closure to being. The question of revealing and concealing never arrives. 


\section{The Openness of Animal Being}

But how do we yet understand this 'open' of the openness of animal being to beings? As mentioned earlier, in discussing organ, organism and drives, drives are not a mechanistic assemblage; the organ is given a capacity by an organism considered as the driven towardness of instinctual drives: "Instinctual drivenness, as being driven from one drive to another, holds and drives the animal within a ring which it cannot escape and within which something is open for the animal" (249). So, on the one hand, the animal cannot apprehend beings as such and on the other hand animal relatedness to things, to environment, is circumscribed by the interrelatedness of instinctual drives constitutive of an organism as a capacity or capability of self-preservation. How to yet speak here of an openness?

Heidegger suggests that the negative manner of considering the 'withholding' of the apprehension of being for animal being may be considered otherwise. He rather emphasises that the animal in its relatedness to beings possesses an "eliminative character" which he will come to define as a "rejecting [of] things from [the] itself [of the animal]" constitutive of the animal's self absorption (252). Eliminative behaviour is the putting to one side, the obviating, of the present at hand, the as such of a being. In this sense, behaviour is a relatedness of a 'not-attending-to' that is yet still open in the sense that an animal in some manner announces itself as affected by things it relates to. Hence an animal is understood as a kind of encirclement of instinctual drives as a "totality of its self-absorbed capability" constitutive of behaviour as relatedness to other things (253). Behaviour is fundamentally eliminative as the non-attending to things as such. Yet the animal announces its capacity to be affected by its environment, and as capacity is the towardness of its preserving in the open of its relatedness. But as capacity, as capability, it is the containment, as inhibition, of its instinctual drives that require disinhibition:

Capability for ... and thus behaviour itself is open for such occasions, for stimuli, for that which initiates, i.e., disinhibits the capability for ... in such and such a way in each case. That which the animal's behaviour relates to is such that this behaviour is open to it. This other is taken up into the openness of the animal in a manner that we shall describe as disinhibition. Since capability for ... thoroughly governs the animal's specific manner of being, a being such as the animal, when it comes into relation with something else, can only come upon the sort of entity that 'affects' or initiates the capability in some way. Nothing else can penetrate the ring around the animal. (254)

Environment in this sense is the relatedness of behaviour to the disinhibitors that are capable of affecting, which is to say that are relatable at all. In such relatedness, the disinhibitors withdraw. Heidegger suggests this is their manner of showing themselves, as that which withdraws and eludes. And it is in this respect that behaviour is eliminative as the not-attendingto. The withdrawal and elusiveness, as the not apprehending of the disin- 
hibitors, coincides with the non-apprehension of the presence at hand. In this, Heidegger suggests, there is no permanence as such, nor any change as such, which is to say, no temporality or historicity as such.

\section{The Poverty of World}

It is not that the animal is trapped in the encirclement of its ring of inhibitors. Rather, this encirclement is precisely the opening to a sphere of disinhibition. And in this sense, animal being cannot be defined, say as 'captivation', and then be shown how it relates to an environment. Its being as captivation is essentially its being related to the separation-reparation of inhibitor-disinhibitor. An animal's being is its self-surrounding with a disinhibiting ring. Its absorption is not with itself in its interiority but with the ring of interrelated instinctual drives in their opening. This discussion of animal being commenced with Heidegger's notion that 'animal is poor in world' while 'man is world forming', and further, that Heidegger wanted to develop a better sense of how animal being is both a having and a not having of world. We may now get a sense of what he might mean. 'Poverty', Heidegger suggests, is intrinsically related to having. One is not poor in something if that something is simply not within one's horizon of disclosure. To be 'poor' already supposes a sense of not having what can be had. Hence, 'poverty' is a 'having' that at the same time constitutes a not-having.

At the same time Heidegger's guiding question concerning 'accessibility' of beings to beings, of animal being and human being to beings, which for Dasein is 'world-forming' in that Dasein can disclose beings as such in their being, must be borne in mind. Both animal being and human being access beings. Animal being accesses beings as behaviour, whose twin fundamental moments of relatedness are the withholding of being in 'elimination' as behaviour's fundamental mode, and the withdrawing of the disinhibitors in the openness of animal being to its environment. It is in this sense that animal is poor in world, though Heidegger emphasises that a valuative understanding of 'poverty' or 'richness' in world is totally misleading. Equally, Dasein's world is meager in comparison to life:

This does not mean that life represents something inferior or some kind of lower level in comparison with human Dasein. On the contrary, life is a domain which possesses a wealth of openness with which the human world may have nothing to compare. (255)

\section{Dasein's World of Boredom: Agamben's Reading}

I suggested at the beginning of this paper that my interest was in assaying Agamben's The Open: Man and Animal. Has this interest been put to one side, and perhaps even eliminated, in a particular captivation with the text of Heidegger? Rather, what has been discussed so far is a preliminary engagement with aspects of Agamben's text, a recounting of salient aspects of his recounting of Heidegger's engagement with animality. I now want to turn to Agamben's concerns more directly, but in doing so, necessarily return to Heidegger's Fundamental Concepts of Metaphysics, and in particular his engagement with 'boredom' as the fundamental attunement of Dasein 
to its being in the world. In what I have said so far about Heidegger's understanding of the poverty of world for animals, there is still something that does not quite make sense. If the animal is fundamentally deprived of access to the apprehension of being, can this be spoken of as deprivation at all? The animal is not open to being but nor is it closed to being. Its 'other' is neither being nor non-being. So in what way does a question of having or not-having emerge at all? That is, if Heidegger wants to make a fundamental distinction between world and environment precisely in terms of the being-disclosed of entities, why say the animal is poor in world at all, as 'world' is never a disclosable entity in the first place?

However, we may begin to see what is at stake for Heidegger, not so much in ascertaining the understanding of disclosure or unconcealment, constitutive of world, but rather in beginning to develop an understanding of concealment or undisclosure or non-revealing. If we speak of a poverty of world, it is precisely in being able to disclose concealment as concealment. And this is where Agamben's reading is addressed. Agamben suggests:

The ontological status of the animal environment can at this point be defined: it is open but not disconcealed, literally openable. For the animal, beings are open but not accessible; that is to say, they are open in an inaccessibility and an opacity-that is, in some way, in a non-relation. This openness without disconcealment distinguishes the animal's poverty in world from the world-forming which characterizes man. The animal is not simply without world, for insofar as it is open in captivation, it must-unlike the stone, which is worldless-do without world, lack it; it can, that is, be defined in its being by a poverty and a lack. (Agamben, 2004: 55)

This 'lack' is fundamental to the animal as captivation, self-absorbing in the emptiness of its behaviour as eliminative, in the emptiness that is its inhibiting capacity. Thus a question of the open for Heidegger oscillates between animal and man, as that between a concealing and a revealing, or an essentiality as concealment and an essentiality as revealing. The 'open' or a questioning of the 'open' brings animal and man into closest proximity in the same moment as it constitutes an abyss separating them. Their proximity is that abyss. Agamben suggests:

Animal captivation and the openness of the world thus seem related to one another as are negative and positive theology, and their relationship is as ambiguous as the one which simultaneously opposes and binds in a secret complicity the dark night of the mystic and the clarity of rational knowledge. (59)

Agamben's argument develops along these lines: that Heidegger's labour or meditation on aletheia and lethe, on the pre-Socratic unconcealment of being and concealment of being are precisely set to work in their depth in his engagement with the animal's poverty of world. In particular, Heidegger dwells here on the mystery of concealment itself, what brings it about, what accomplishes or gives concealment. Agamben's thesis is that Heidegger is 
here meditating on the profound nature of Dasein as animal being, as that withdrawing, saving and preserving of the being of Dasein in Dasein's revealing of the concealing of what gives being. In this Dasein reveals bare life as its ownmost concealed proximity to being. Heidegger's own engagement in revealing this proximity is through his development of the fundamental attunement of Dasein to its being in the world as 'profound boredom'. Hence the preceding of Heidegger's discussion of animality in the Fundamental Concepts of Metaphysics with some one hundred pages on 'boredom'.

\section{Boredom's Indifference to Beings}

Briefly, Heidegger works through three stages of 'boredom' to arrive at 'profound boredom'. What is uncanny is that the terms he used to describe Dasein's relation to being in these stages will quite closely coincide with his description of the animal's relatedness to its environment, that Dasein's boredom and the open of animal being are coincident or proximal if at the same time abyssal. The three 'forms' of boredom are structured around two moments defining the essence of boredom. The first is 'being left empty' or 'abandonment in emptiness': "Leaving empty as refusal indeed presupposes something at hand, but what is at hand must precisely be something particular and something expected in a particular situation, so that we can come to be left empty by something, in the sense of becoming bored by ..." (Heidegger, 1995: 104). He contrasts this 'being left empty' with things by an account of being 'satisfied' with things in our dealings with them, in our immersion with them. Heidegger will in fact use terms identical to those he will come to use in defining an animal's captivation: "Being occupied gives our dealings with things a certain manifoldness, direction, fullness. But not only that: we are also taken by things, if not altogether lost in them, and often even captivated by them" (101). Hence in being occupied, Dasein may be taken, captivated, or left empty.

In boredom, the totality of Dasein's disclosed world shows beings in their 'indifference', in the emptiness of possibility for action. This disclosure is a disclosure of beings that refuse themselves. Agamben suggests:

Dasein can be riveted to beings that refuse themselves in their totality because it is constitutively 'delivered up' to its own 'proper being,' factically 'thrown' and 'lost' in the world of its concern. But, precisely for this reason, boredom brings to light the unexpected proximity of Dasein and the animal. In becoming bored, Dasein is delivered over to something that refuses itself, exactly as the animal, in its captivation, is exposed in something unrevealed. (Agamben, 2004: 65)

Hence both man and animal are here open to a closedness, given over to what remains concealed. The second moment of boredom develops from the first. If the indifference of Dasein's world of things lights up as the emptiness of possibility for action, for concernful underwayness in Dasein's projection that is its being-in-the-world, this emptiness, from the point of view of possibility, capacity or capability, is a 'being-held-in-suspense' which alerts Dasein to what it could have done, its possibilities, possibili- 
ties as such, delivered precisely as the withholding of possibility, as the withholding of the disclosure of beings, the "telling announcement of possibilities left unexploited" (Heidegger, 1995: 141). Being-held-in-suspense, in the revealing of the inactivity of Dasein with respect to the totality of its being, is the alerting to Dasein of its potentiality as such for being, of the "possibilitisation proper to Dasein" (66). The revealing of Dasein as possibility or potentiality for being is precisely a revealing of an utmost concealing, of a potential-not-to, of a holding in suspense of Dasein's disclosed world of things. As Agamben suggests:

Thus, the proximity, and at the same time the distance, between profound boredom and animal captivation finally come to light.... The animal environment is constituted in such a way that something like pure possibility can never become manifest within it. Profound boredom then appears as the metaphysical operator in which the passage from poverty in world to world, from animal environment to human world, is realized; at issue here is nothing less than anthropogenesis, the becoming Dasein of living man. (68)

What is revealed as Dasein's openness to being is nothing other than an openness to the animal's disinhibitor ring, to the concealedness of this ring, its withdrawal in animal being. This is an openness to the closedness, the concealed of life's own open: "Dasein is simply an animal that has learned to become bored; it has awakened from its own captivation to its own captivation. This awakening of the living being to its own being captivated, this anxious and resolute opening to a not-open, is the human" (70).

\section{Animal Impulse and the Biopolitics of Bare Life}

I suggested earlier that Agamben moves these concerns with Heidegger's disclosure of man and animal towards his own concerns with the question of the biopolitical. In a book that might be described as bleak and uncompromising, Agamben introduces the notion of 'bare life' as the political substance of modernity. Homo Sacer: Sovereign Power and Bare Life takes up Foucault's analysis of biopower as modernity's invention of an exercise of power in its operations on the corporeal reality of populations as the management of the (bare) animal life of humans. This may be thought of in terms of the circular movement of the twin terms: the total humanisation of the animal and the total animalisation of the human. As a summary to his analyses, Agamben suggests:

(i) The original political relation is the ban (the state of exception as zone of indistinction between outside and inside, exclusion and inclusion).

(ii) The fundamental activity of sovereign power is the production of bare life as originary political element and as the threshold of articulation between nature and culture, zoe and bios.

(iii) Today it is not the city but rather the camp that is the fundamental biopolitical paradigm of the West. 
The first of these calls into question every theory of the contractual origin of state power and, along with it, every attempt to ground political communities in something like a 'belonging', whether it be founded on popular, national, religious, or any other identity. The second thesis implies that Western politics is a biopolitics from the very beginning, and that every attempt to found political liberties in the rights of the citizen is, therefore, in vain. The third thesis, finally, throws a sinister light on the models by which social sciences, sociology, urban studies, and architecture today are trying to conceive and organize the public space of the world's cities without any clear awareness that at their very centre lies the same bare life (even if it has been transformed and rendered apparently more human) that defined the biopolitics of the great totalitarian states of the twentieth century (Agamben, 1998: 181-182).

With his later publication, The Open, Agamben brings these theses into the arena of Heideggerian thinking, and in doing so seems to offer two proposals where Homo Sacer seemed to deliver a singular message. Indeed, the bleakness of Homo Sacer is precisely the fundamental figuring of the biopolitical as a totalitarianism abetted precisely by appeals to the contractual relations of human rights. One cannot say that, for Agamben, Heideggerian thinking alleviates anything; but it does, at a crucial juncture, suggest another path of thinking. For Heidegger, the polis is fundamentally that place of questioning the question of unconcealment and concealment, which is to say the political paradigm for Heidegger revolves about this pole, this turning of the question of the question of revealing and concealing. Agamben gives to Heidegger's lethe, concealment, the proper name, animal, and to unconcealment, aletheia, the disclosure that is Dasein. Hence, with respect to Agamben's theses concerning the biopolitical, the ban as abandonment, state of exception or zone of exclusion marks precisely the having-not-having of world that is constitutive of bare life, or the animal life of humanity, just as bare life, lethe, concealment is the original political substance as that constitutive of the unconcealing of the pure possibility of Dasein itself as pure potentiality for the letting be of its own concealed being. And what of the two scenarios suggested by Agamben? After having suggested that the decisive political conflict today is that between the animality and the humanity of man, he goes on to say:

At this point two scenarios are possible from Heidegger's perspective: (a) posthistorical man no longer preserves his own animality as undisclosable, but rather seeks to take it on and govern it by means of technology; (b) man, the shepherd of being, appropriates his own concealedness, his own animality, which neither remains hidden nor is made an object of mastery, but is thought as such as pure abandonment. (Agamben, 2004: 80)

While the first of these options constitutes the accounting for modernity in Homo Sacer, in terms of technologies of power productive of the global ordering of life, the second no less abandons the fragile vulnerability of bare life as political substance, in the sense that bare life is constitutive of the political as such. Our recourse, then, is not the abandonment of zoe for a renewal of bios, abandoning the lethe of animal being for the humanitas of culture building. Indeed, even Heidegger suggests the post-history of this 
recourse. Rather, our recourse (but who is this 'our' in Agamben's context of the totalitarianism constitutive of 'community'?) is a certain suspension of the question, which is itself already the question of suspension itself: holding open the openness of possibility as such to the revelation that there is being as such. Agamben addresses this doubling of suspension directly, as perhaps the horizon of a politics that has always been the stakes of the political as such:

In so far as the animal knows neither beings nor nonbeings, neither open nor closed, it is outside of being; it is outside in an exteriority more external than any open, and inside in an intimacy more internal than any closedness. To let the animal be would then mean to let it be outside of being. The zone of nonknowledge-or of aknowledge- that is at issue here is beyond both knowing and not knowing, beyond both disconcealing and concealing, beyond both being and the nothing. But what is thus left to be outside of being is not thereby negated or taken away; it is not, for this reason, inexistent. It is an existing, real thing that has gone beyond the difference between being and beings. (91-92)

The politics of bare life would then amount to the recognition of the emptiness, the 'hiatus' that separates, within the human, man and animal, and to risk ourselves in this emptiness. This would constitute for Agamben the positive figure of the zone of exception, or bare life, that would recognize in the impulse neither the singular element of a fundamental behavioral training nor the sub-species signature of life itself, but rather the trace of an outside of being that would at the same time be the withdrawn giving of the concealed as such.

\section{References}

Agamben, G. (1998). Homo sacer: Sovereign power and bare life (D. Heller-Roazen, Trans.). Stanford: Stanford University Press. (Original work published 1995.)

Agamben, G. (2004). The open: Man and animal (K. Attell, Trans.). Stanford: Stanford University Press. (Original work published 2002.)

Heidegger, M. (1999). Ontology - the hermeneutics of facticity (J. van Buren, Trans.). Bloomington \& Indianapolis: Indiana University Press. (Original work published 1988.)

Heidegger, M. (1995). The fundamental concepts of metaphysics (W. McNeill \& N. Walker, Trans.). Bloomington \& Indianapolis: Indiana University Press. (Original work published 1983.) 